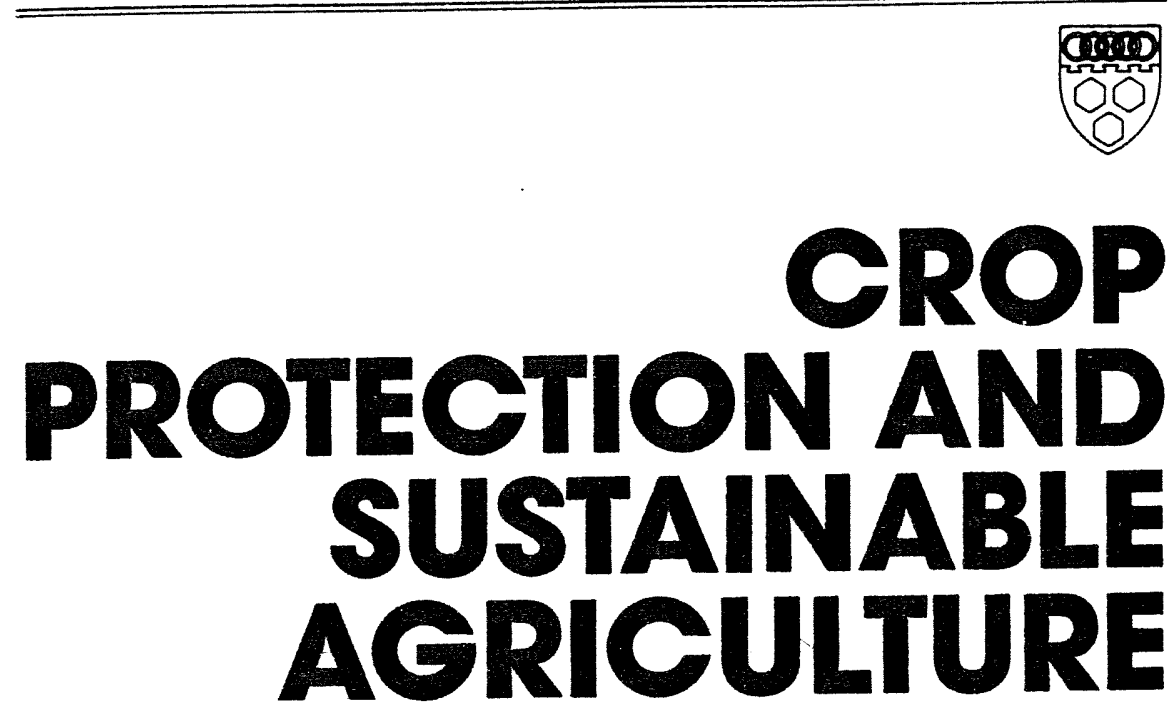

A Wiley-Interscience Publication

R. Rabbinge The ecological background of food production 2 Discussion 23

JOHN WILEY \& SONS 


\title{
The ecological background of food production
}

\author{
R. Rabbinge
}

Department of Theoretical Production Ecology, Wageningen Agricultural University, PO Box 430, NL.6700 AK Wageningen, The Netherlands

\begin{abstract}
In the industrialized countries dramatic decreases in the number of people employed in agriculture have been made possible by a rise in soil and labour productivity. There is scope for these to improve further, particularly in developing countries. Potential yields are determined by the characteristics of the crop, local temperature and sunlight. Because the availability of nutrients and that of water are limiting for at least part of the growing season in most agricultural lands, attainable yields are lower than potential yields. Proper management of nutrient inputs, such that optimum use is made of each, can reduce this gap without causing negative environmental side-effects. Actual yields are lower than attainable yields because of growth-reducing factors, such as pests, diseases and weeds. For sustainable agriculture these should be controlled mainly by biological measures. There are many possibilities for this, thus biocides may be used as a last resort not as preventive insurance. Potential yields of rice and sugarcane can reach $30000 \mathrm{~kg} \mathrm{ha}^{-1}$ per year of consumable organic matter, sufficient to feed 120 people. Such yields cannot be achieved on all agricultural land, but it is estimated that world food production could support a population of 80 thousand million, if they were all vegetarian and required only $1500 \mathrm{~m}^{2}$ for non-food-related purposes. The green revolutions that occurred in the Western industrialized countries in the late 1940s and early 1950s and in Asia in the late 1960s and early 1970 s need to be followed by a similar increase in agricultural productivity in Africa and West Asia to feed their rapidly growing populations. Better use of fertilizers and good water management require well-educated farmers with the financial means to implement long-term strategies. If these developments are managed properly, food production for the ever-increasing human population can be guaranteed and the burden on the environment and natural habitats reduced, enabling the development of sustainable agricultural systems.
\end{abstract}

1993 Crop protection and sustainahle agriculture. Wiley, Chichester (Ciba Foundation Symposium 177) p 2-29

For centuries, food production was the primary occupation of the majority of the population, and in most countries in the world this remains true. The situation is changing rapidly; for example, until 1860 in The Netherlands more than $50 \%$ of the working population was engaged in agriculture, today it is 
only $5 \%$. In other industrialized countries this percentage is even lower, because non-soil-dependent agriculture and horticulture (greenhouses, mushroom cultivation, intensive livestock farming) are more developed in The Netherlands than elsewhere.

The enormous changes in the number of people employed in agriculture have been caused by a rise in soil and labour productivity due to the use of products developed by industry. Investments in land reclamation, mechanization, improvement of soil fertility and crop protection are possible only if industry produces the machines, the fertilizers and the crop protection technologies and agents required. There is scope for soil and labour productivity to increase in $99 \%$ of the world's agricultural areas. If these developments are managed properly, food production for the ever-increasing population can be guaranteed and the burden on the environment and natural habitats reduced, enabling the development of sustainable agricultural systems.

\section{History of agriculture}

In the early middle ages, French farmers produced some $800 \mathrm{~kg}$ of grain per hectare each year of which, because of its poor quality and competition with weeds, $200 \mathrm{~kg}$ were needed as seed for the next year's crop. The low level of mechanization meant that it took at least 500 hours to cultivate each hectare. North-western Europe's highly productive agriculture now produces around $7500 \mathrm{~kg}$ of grain per hectare per year. No more than $150 \mathrm{~kg}$ of seed and 15 hours of work are required for each hectare.

The cause of the low yields per hectare in early medieval times was not the climatic conditions but the chronic shortage of nutrients. Natural fertilization provides only $25 \mathrm{~kg}$ of nutrients to plants (nitrogen, phosphate and potassium). In combination with solar energy, this is just enough to produce $1500 \mathrm{~kg}$ of biomass, of which $50 \%$ is stems, leaves, etc.

Certain agricultural practices, such as the spreading of animal manure or the use of green manure (e.g. clover), increased production. The most important source of plant nutrients was animal manure and the main purpose of keeping large herds on uncultivated land was to improve soil fertility. By the beginning of the 20th century, yields rose to $2000 \mathrm{~kg}$ per hectare per year on well-managed land, to which large amounts of animal manure and/or green manure were applied. The small population enabled land to be used in this way in Europe. Enough rangeland was available on which cattle could be kept and thereby enhance soil fertility in concentrated areas where, for example, grain was grown. In other parts of the world, such as China and India, the pressure on agricultural land was much greater and the level of production remained at around $1000 \mathrm{~kg}$ of grain per harvest.

In industrializing north-western Europe, population growth increased dramatically in the 19th century and it became impossible to feed everyone on the traditional diet of meat and grain. The introduction of the potato and the 
replacement of animal fats by vegetable fats enabled many more people to be fed. In potato $80 \%$ of the dry matter formed ends up in the harvestable product, the tuber, while for cereals this is only $50 \%$. Crop rotation was employed on a large scale and food crops were alternated with clovers, grasses and other crops used for animal feed. Manure was carefully stored and urban waste was composted and used to improve soil fertility. In other parts of Europe, yields remained extremely low, less than $1000 \mathrm{~kg}$ of grain per hectare.

\section{Agriculture with fertilizers}

Large-scale increases in yield became possible only after industry began to produce fertilizers. In 1840 the German chemist Liebig showed that plants require only water, minerals and nitrogen from the soil. Organic matter has no nutritional significance, but affects the structure and texture of the soil. Liebig's experiments showed that only $25 \mathrm{~kg}$ of the nutrient nitrogen is available to the plant if no fertilizer is applied. By applying minerals to the soil, the level of nutrients, and therefore also yield, could be raised. It was not until several decades after Liebig's discovery that farmers became aware of it and industry began to produce mineral fertilizers. Conditions changed rapidly after that. Up to 1900 productivity rose at a rate of some $3-4 \mathrm{~kg}$ of dry matter per hectare per year, after which the rate increased to approximately $15 \mathrm{~kg}$ per hectare per year until, after the Second World War, productivity experienced a dramatic increase (see Fig. 1).

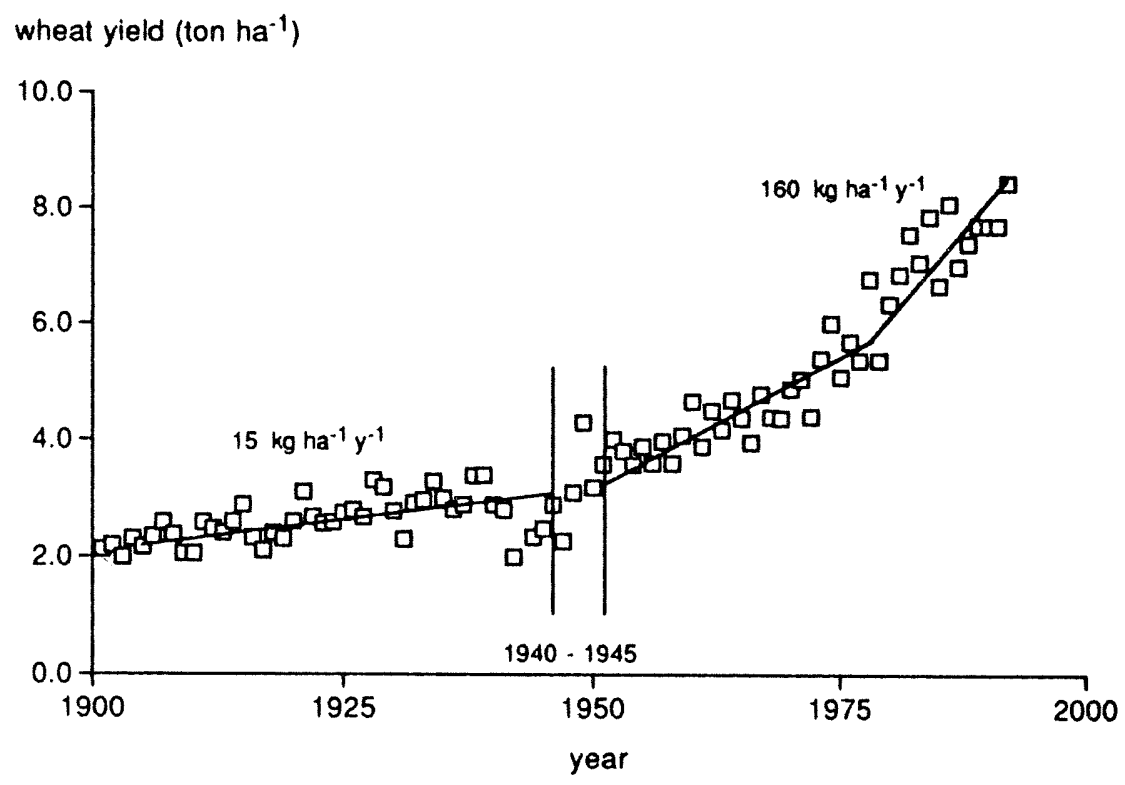

FIG. 1. Wheat yields in The Netherlands. 
TABLE 1 Characteristics of old and new varieties of winter wheat grown under optimal conditions at Cambridge, UK 1984-1986

\begin{tabular}{|c|c|c|c|c|}
\hline $\begin{array}{l}\text { Variety } \\
\text { group }\end{array}$ & $\begin{array}{l}\text { Total above- } \\
\text { ground dry } \\
\text { matter } \\
\text { (ton ha-1) }\end{array}$ & $\begin{array}{l}\text { Grain yield } \\
\text { (85\% dry } \\
\text { matter) } \\
\text { (ton ha-1) }\end{array}$ & $\begin{array}{l}\text { Harvest index } \\
\text { (on basis of } \\
\text { above-ground } \\
\text { dry matter) }\end{array}$ & $\begin{array}{l}\text { Stem } \\
\text { length } \\
\text { (cm) }\end{array}$ \\
\hline Very old & 15.0 & 5.94 & 0.34 & 145 \\
\hline Old & 15.4 & 6.55 & 0.36 & 134 \\
\hline Intermediate & 14.8 & 7.87 & 0.45 & 96 \\
\hline Modern & 15.9 & 9.47 & 0.51 & 78 \\
\hline
\end{tabular}

Taken from Austin et al (1989).

Current wheat yields in The Netherlands are approximately $8000 \mathrm{~kg}$ per hectare-five times the level at the beginning of this century and twelve times the level in the middle ages. The figures for productivity per unit labour are even more striking - this is now 200 times higher than in the middle ages. This dramatic rise in productivity has enabled large numbers of workers to leave agriculture, and was possible partly because enough jobs were created in other sectors of the economy to absorb the displaced labour. The current high yields are the result of the $200 \mathrm{~kg}$ of nutrients applied to each hectare every year, in addition to the nutrients available to plants from the manure produced by animals which during the winter are fed on silage grass and maize, and imported feed. This increase in yield through the use of mineral fertilizers was possible only thanks to the introduction of new varieties, which began in 1840 . Some crops, such as buckwheat, were not adapted and play no important role in food provision. Among the cereal crops, the varieties which tiller (develop secondary shoots) readily were gradually replaced by varieties which produce stiff straw (Table 1).

However, the rise in yield over the last hundred years was limited not so much by technical possibilities, as by the demand for food and the ability of the population to pay for it. Since the mid-19th century, farmers have been able to produce all the food required, but only over the last thirty years, at least in Western Europe, the USA and some countries in South America, has income become distributed in such a way that everyone can afford to buy the food they need. This is not true for many countries in Asia which experienced a structural food shortage in the early 1950 s. Since the late 1960 s, the food production situation has improved considerably, but it is questionable whether this remains so.

\section{Potential, attainable and actual production levels}

\section{Potential production}

In the industrialized countries, the yield of agricultural crops is still rising rapidly (Fig. 1), despite already being at a high level. This increase cannot continue 
indefinitely, however, and the question arises: what maximum yields can be achieved, using good varieties, provided with sufficient minerals, nitrogen and water? Total production of organic matter under such conditions depends on the rate of photosynthesis in the green leaves of the crop, expressed as $\mathrm{kg} \mathrm{CO}_{2}$ per hectare per hour. In a single leaf, photosynthesis is directly proportional to light intensity at lower intensities, but at higher light intensities the rate of photosynthesis reaches an upper limit (Fig. 2).

Before light saturation is reached, the slope of the curve does not vary significantly among plant species. The production of sugars at low light intensities is around $0.3 \mathrm{~kg} \mathrm{ha}^{-1}$ per hour for every Joule absorbed by $1 \mathrm{~m}^{2}$ of leaf per second. However, the maximum rate of photosynthesis does vary significantly among species. There are two types of photosynthesis: $C_{4}$ and $C_{3}$ photosynthesis, named after the number of carbon atoms in the first molecule formed after fixation of atmospheric $\mathrm{CO}_{2}$. The majority of plants have $\mathrm{C}_{3}$ photosynthesis; only a few (several tropical grasses and crops such as maize and sugarcane) have the $C_{4}$ type. At high light intensities, photosynthesis is lower in $C_{3}$ plants. This is mainly the result of photorespiration which in $\mathrm{C}_{3}$ crops increases in proportion to light intensity, but does not occur in $\mathrm{C}_{4}$ crops. The average maximum rate of photosynthesis in the individual leaves of many of the important agricultural crops, legumes and trees is approximately $20 \mathrm{~kg}$ of sugars ha-1 per hour. Some tropical crops produce yields at least double these at favourable temperatures.

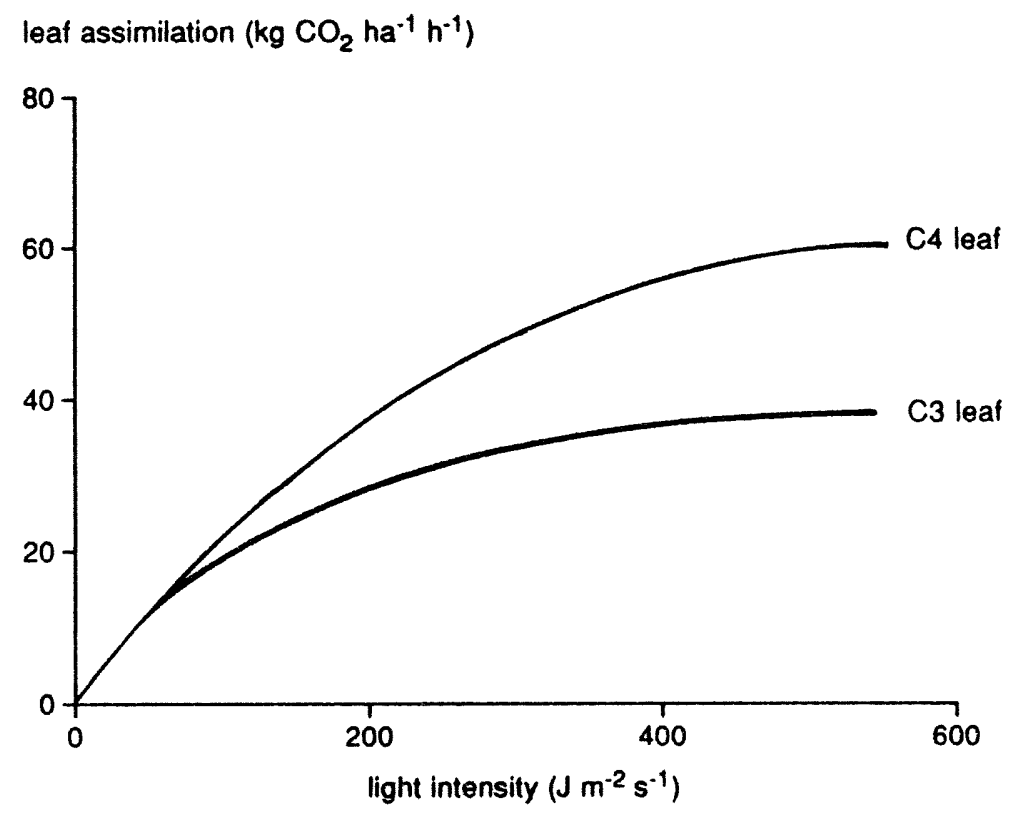

FIG. 2. The production of organic matter in leaves varies with the light intensity. 
At light intensities of approximately $100 \mathrm{~J}$ per $\mathrm{m}^{2}$ per second the leaves of $\mathrm{C}_{3}$ crops have virtually reached their maximum rate of photosynthesis. Such intensities are reached on cloudy days when the sun stands at its zenith; on clear days, intensities of up to $1000 \mathrm{~J}$ per $\mathrm{m}^{2}$ per second may occur. A high proportion of the light reaching crops with one or more layers of large, horizontally positioned leaves is lost. Many crops have narrow leaves arranged in various positions so that light can penetrate deeper into the crop and is therefore distributed more evenly over the leaves.

de Wit (1972) calculated that on a completely clear day closed crops (in which virtually all light is intercepted) whose individual leaves have a maximum photosynthetic rate of $20 \mathrm{~kg}$ of sugars ha-1 per hour and a leaf arrangement like that of a cereal crop, photosynthesize at rates of 35,50 and $55 \mathrm{~kg}$ of sugars $\mathrm{ha}^{-1}$ per hour when the sun stands at an angle of $30^{\circ}, 60^{\circ}$ and $90^{\circ}$ above the horizon, respectively. When the sky is cloudy, light intensities are approximately one fifth of those found under clear conditions. However, the rate of photosynthesis is reduced by no more than one half because light is distributed more evenly throughout the crop under cloudy conditions and because photosynthesis uses proportionally more of the light energy at lower light intensities. In The Netherlands, potential photosynthesis is approximately $400 \mathrm{~kg}$ of sugars ha-1 per day in summer and $200 \mathrm{~kg} \mathrm{ha}^{-1}$ per day in spring and autumn. If the daily totals from mid-April to mid-October are added, potential photosynthesis of a healthy crop surface is approximately $50000 \mathrm{~kg}$ of sugars ha-1.

The sugars produced are not stored as such, but are used by the plant to produce its roots, stems, leaves, flowers, fruits and seeds. The production of $1 \mathrm{~g}$ of proteins, fats or cellulose and absorption of $1 \mathrm{~g}$ of minerals requires 1.92 , $3.23,1.28$ and $0.12 \mathrm{~g}$ of sugar, respectively. For $1 \mathrm{~g}$ of plant material containing $25 \%$ protein, $5 \%$ fat, $60 \%$ cellulose and $10 \%$ minerals by weight, $1.42 \mathrm{~g}$ of sugar is needed. This means that the rate of $400 \mathrm{~kg}$ of sugars ha-1 per day which is possible in June produces a plant growth of $275 \mathrm{~kg}$ of organic matter $\mathrm{ha}^{-1}$ per day. Roughly one quarter of this organic matter is used in respiration. Therefore estimates of potential yield must assume production of $200 \mathrm{~kg}$ of dry matter ha-1 per day. This growth rate actually occurs in The Netherlands under favourable conditions (Fig. 3).

\section{Attainable and actual production}

Potential yield is achieved only under exceptional conditions. Usually, the attainable yield is considerably lower, because for part or even all of the growing season, growth is restricted by shortage of water and/or nutrients. In addition, crops are plagued by diseases, pests and weeds. In the majority of the world's agricultural regions, the attainable yield is less than $20 \%$ of the potential yield. The actual yield is generally even lower, because agricultural practices are not carried out optimally. 


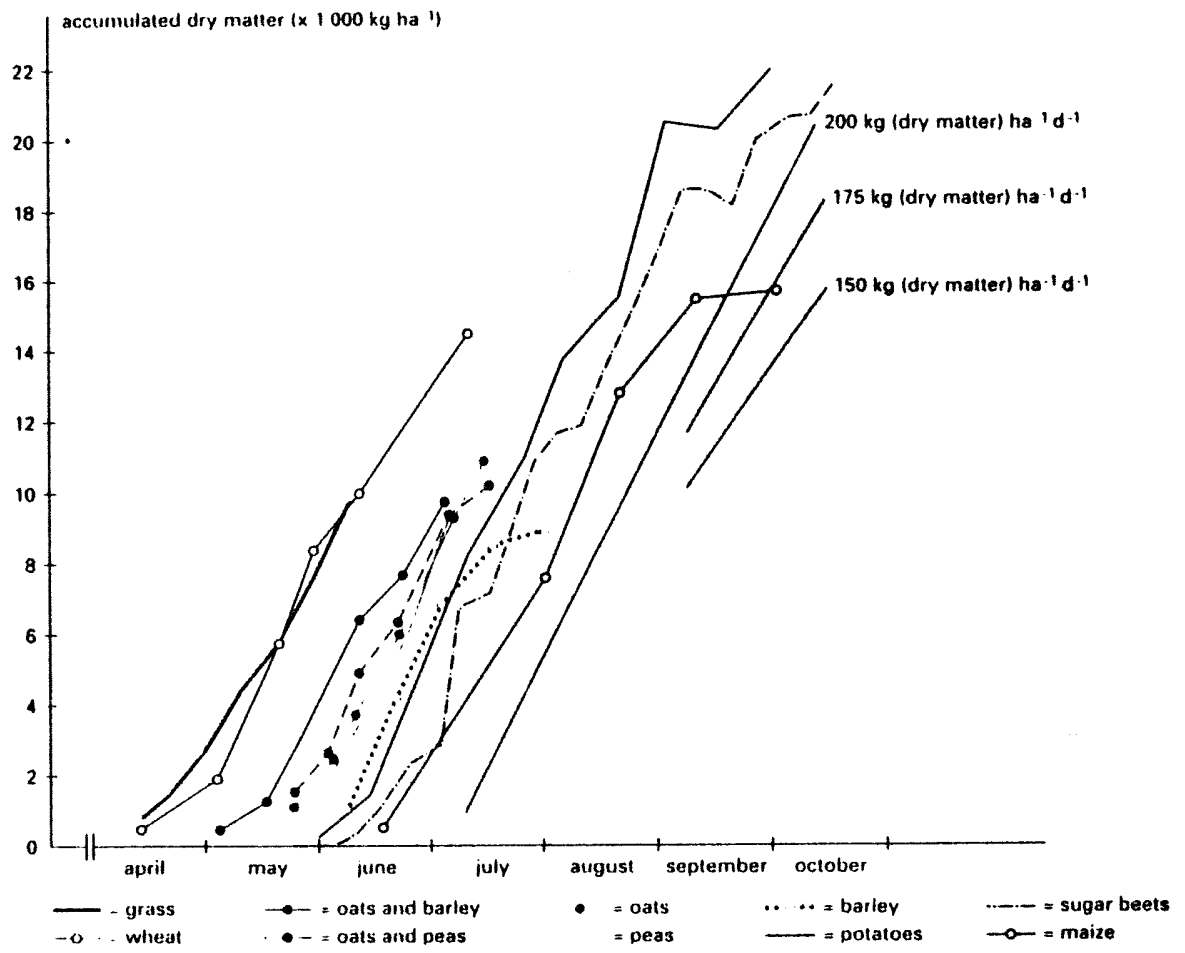

FIG. 3. Growth rates of different crops in The Netherlands throughout the growing season. The growth curves correspond fairly closely to the theoretical production rate of $200 \mathrm{~kg}$ of dry matter ha ${ }^{-1}$ per day. From Sibma (1968).

In areas with a high level of land reclamation, which is the case for most of the world's agricultural land, actual yield is often further below attainable yield than in areas with a low level of land reclamation. The difference between high and low levels of reclamation can be seen in the degree to which attainable production approximates potential production. Actual yield can be raised to the level of attainable yield by the use of good cultivation practices, particularly in areas with a high land reclamation level. One can thus differentiate between potential, attainable and actual yield.

The potential yield is determined by growth-defining factors, i.e. incoming solar radiation and temperature and the characteristics of the crop. These include physiological (photosynthetic) characteristics, its phenological characteristics (crop development), the optical properties of the leaf (reflection, transmission and absorption of radiation) and its geometric characteristics (leaf arrangement and ability to intercept radiation).

The attainable yield is that which can be achieved under conditions of suboptimal amounts of growth-limiting factors (see Fig.4). In virtually all the 


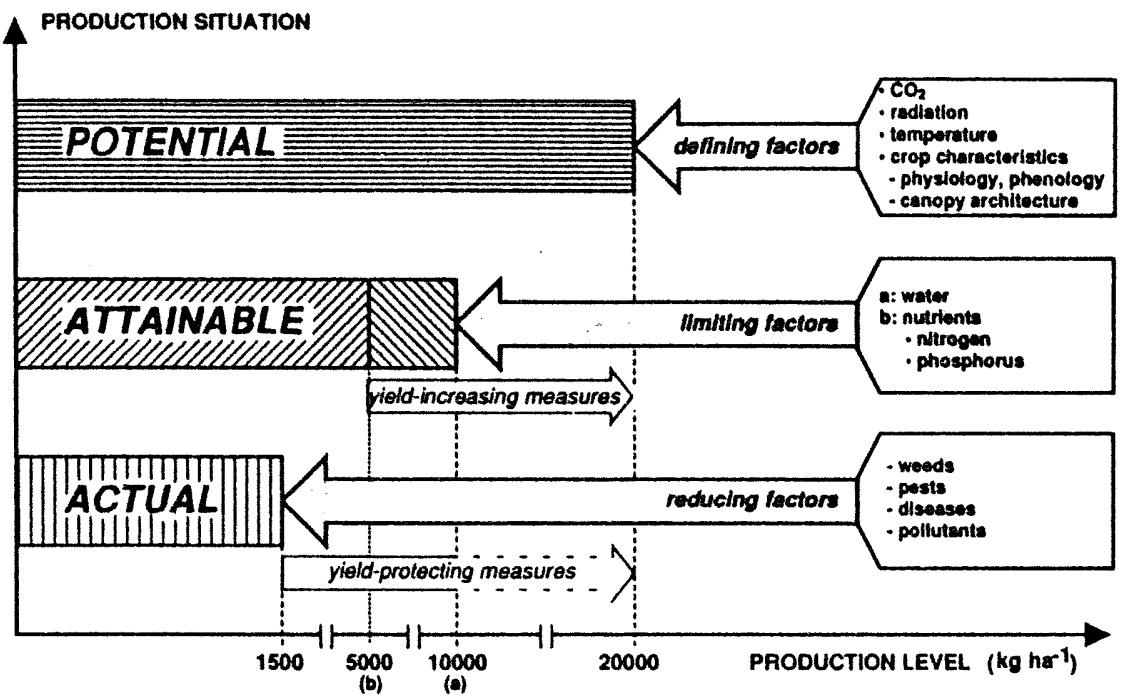

FIG. 4. The relationships among potential, attainable and actual yields and growthdefining, growth-limiting and growth-reducing factors.

agricultural areas of the world, growth rate and, therefore, production are limited during at least a part of the growing season by a shortage of water and nutrients. An analysis of growth and production of Sahelian rangelands showed that for part of the growth period phosphate is in short supply, then nitrogen; at other times shortage of water is the limiting factor. If the problem of poor soil fertility were eliminated, the attainable yield would be 2-5 times the present yield. Despite appearances, water is not the sole growth-limiting factor in this case.

Factors which reduce growth include diseases, pests and weeds, and these also reduce the attainable yield. The prevailing weeds, pests and diseases at low production levels are different from those at high production levels. Crop growth-limiting and crop growth-reducing factors interact. Quantification of the effect of these factors on the underlying processes of light interception, assimilation, respiration and transpiration and the effect on, for example, water and nutrient uptake and integration in models of crop growth, helps in understanding the various growth-reducing factors and provides a basis for the development of control measures.

Weeds compete with crops for environmental resources that are in limited supply. Mechanical and chemical weeding methods may be applied. Timing and appropriate control methods depend on detailed knowledge of the consequences of weed occurrence and activity during various development stages (Kropff et al 1984). Pests and diseases affect crop growth at all production levels, but are important at only some. 
The impact of pests and diseases on crop performance depends on the mode of interaction, which is determined by the morphological and physiological characteristics of both crop and the pest or disease agent, and their interaction with environmental conditions. A similar approach may be followed for pollutants, when their point of impact in plant processes is unravelled. The effects of pests and diseases can be incorporated into a crop growth simulation model, and thereby quantified. Some of these interactions will be exemplified for a number of pests and diseases.

\section{Crop growth-reducing factors}

Stand reducers. Organisms such as damping-off fungi or caterpillars in massive numbers negatively affect plant density. This may decrease yield unless remaining plants have the ability to compensate for these losses by increased tillering, branching or locally increasing leaf area.

Light stealers. The assimilation rate may be reduced by a direct effect of the pathogen on light use efficiency through 'light stealing'. Some leaf pathogens (e.g. perthotrophic and saprophytic fungi) cause the death of host tissue, which may remain and absorb radiation without assimilation taking place and reduce light penetration into lower leaf layers. The mycelium produced may cover surfaces of living leaves and reduce light absorption or interfere directly with photosynthesis (see assimilation rate reducers, below) through excretion products or necrotic lesions.

Assimilation rate reducers. Many pathogens decrease the assimilation rate by changing the physiological properties of the leaf. Viruses (e.g. beet yellows virus on sugar beet) and some fungi may affect the photochemical and biochemical processes in chloroplasts (reflected in lower values of both $A_{\max }$ and $\epsilon$ ) or reduce the number of chloroplasts per unit leaf area. Bacteria may cause structural damage to chloroplasts. Some pathogens and insects may accelerate leaf senescence. Other pathogens such as rusts may perturb functioning of the stomata, resulting in higher resistance to $\mathrm{CO}_{2}$ uptake and hence a lower assimilation rate.

Assimilate sappers and tissue consumers. Assimilate sappers feed on primary assimilates (e.g. aphids and mites drain assimilates from the parenchymal cells), while tissue consumers remove crop tissue (e.g. cereal leaf beetles). Since each $\mathrm{kg}$ of glucose produces less than $1 \mathrm{~kg}$ of structural dry matter, tissue consumers are more detrimental in terms of crop growth per unit weight consumed. However, secondary effects of assimilate consumers (e.g. interaction with plant physiological processes, attraction of other pathogens), may result in greater total growth reduction. 
Some pathogens affect the turgor of cells, either directly by suction or by disrupting the tissue such that transpiration increases. The water balance of a plant may also be affected by root pathogens and nematodes that feed on the roots. These may also disturb the crop nutrient balance by interfering with phloem transport to the roots, thereby reducing energy availability for active uptake of nutrients, and by disrupting the passive flow of water and nutrients because of decay of conducting tissue.

Pollutants. Chemicals such as heavy metals and gases may reduce crop production as they reach toxic levels. At this point, plant physiology may be influenced through competition (nutrient uptake, gas exchange) or through modification of environmental conditions at cell level (osmotic strength, acidity).

\section{Control of pests and diseases}

Because pest and disease infestations are fundamentally different from weeds, in terms of mobility and interactions with plants, control operations have to be adapted accordingly. Timeliness of the control measures is crucial.

Preventive measures against pathogens include removal and destruction of crop residues to reduce contamination potential; crop rotations including fallowing to reduce nematode and other soil pathogen populations (e.g. in greenhouses); crop breeding for resistance against pathogens. However, in many cases pathogens break crop resistance after some time, so that the breeder has a 'race without an end'.

Preventive measures against pests include the use of repellents, pheromones (to attract enemies), nets for some insects and birds or fencing for animals. Breeding in this context primarily aims at modifying morphological characteristics, such as taller spikelets in wheat to hamper bird attacks. Such modifications may unfavourably affect harvesting procedures.

Curative control is based largely on the use of biocides, but both pathogens and pests may develop resistance against chemicals. Biological control agents (such as wasps, killing larvae or whitefly) are widely studied and tested. In designing proper techniques for these control measures, modelling of population dynamics is an important tool.

Finally, technology is applied to protect the harvested products. Preventive measures include drying, cooling, heating, acidification and fumigation, some of which can also be used curatively.

\section{Potential production in the world}

As indicated earlier, potential photosynthesis in The Netherlands is around $50000 \mathrm{~kg}$ of sugars or $35000 \mathrm{~kg}$ of organic matter ha ${ }^{-1}$ per year. Given that part of this is needed for respiration and that only part of the biomass is suitable 
for human consumption, we can assume that, with our current level of knowledge and the crop varieties available, it should, in a commercial setting, be possible to obtain $35 \%$ of the biomass in a form suitable for human consumption. There are $14 \mathrm{MJ}$ per $\mathrm{kg}$ of dry matter so this comes to $175 \mathrm{GJ}$ $\mathrm{ha}^{-1}$ per year. Since one person requires $3.5 \mathrm{GJ}$ of energy each year, in The Netherlands one hectare could feed around fifty people a year, assuming that they ate only vegetable products and did not waste much food. In other parts of the world potential production differs, depending on the length of the growing season, the temperature and the level of solar radiation. If enough nutrients and water are supplied, it is possible to grow crops all year round in the tropics. This gives a potential photosynthesis of some $120000 \mathrm{~kg}$ of sugars ha-1 per year, or a production of approximately $30000 \mathrm{~kg}$ of organic matter suitable for consumption, which could feed 120 people for a year. These yields have been shown to be attainable with crops such as rice and sugarcane.

These calculations demonstrate that the world population, which currently stands at over five thousand million persons, could, under European conditions, feed itself from an area of 100 million ha. The current amount of agricultural land in the European Community is 127 million ha. However, by no means all of this land is capable of producing such high yields. Less than $60 \%$ of the cultivated land in Europe would be capable of reaching such levels of production. Nevertheless, the potential for food production is unimaginably big. Naturally, a situation in which Europe grew food to feed the rest of the world is highly unlikely, but it demonstrates the enormous potential of agricultural production. In fact, this theoretical situation illustrates the upper limits of cultivation practices, although it does not take into account the socio-economic and ecological constraints.

If potential production is achieved, $150 \mathrm{~m}^{2}$ is required for food for one person and more than $1 \times 10^{12}$ people could live from the total land area (excluding the oceans) (Table 2). This figure is more than 200 times the current world population. However, this number of people could live from the earth, but would not have enough space to live on the earth.

Estimates of the amount of land one person needs for food, work and relaxation depend strongly on the cultural background of the person making the estimate. If we assume that at least five times the area needed for food is needed for other purposes, we obtain $750 \mathrm{~m}^{2}$ per person. This is still a small area and has been calculated rather arbitrarily.

On the basis of this figure and an average of $150 \mathrm{~m}^{2}$ for food production, a total of $900 \mathrm{~m}^{2}$ per person is required. This allows for a maximum world population of $145 \times 10^{9}$. In The Netherlands, 15 million people live on some $30000 \mathrm{~km}^{2}$, approximately $20000 \mathrm{~km}^{2}$ of which is used for agriculture and horticulture. This population should require only $20 \%$ of the land area for its own food production, rather than the current $60 \%$. This land, suitable for modern agricultural practices, is available. 
TABLE 2 The potential production of all land area between $70^{\circ} \mathrm{N}$ and $50^{\circ} \mathrm{S}$ and the potential number of people who could be fed

\begin{tabular}{|c|c|c|c|c|c|}
\hline $\begin{array}{l}\text { Degrees } \\
\text { North }\end{array}$ & $\begin{array}{l}\text { Total } \\
\text { land } \\
\text { area } \\
\left(10^{8} \text { ha }\right)\end{array}$ & $\begin{array}{l}\text { Months } \\
\text { with } \\
\text { with temp } \\
>10^{\circ} \mathrm{C}\end{array}$ & $\begin{array}{l}\text { Total organic } \\
\text { matter (1000 kg } \\
\text { ha per year) } \\
\text { (potential } \\
\text { production) }\end{array}$ & $\begin{array}{l}\text { Area required } \\
\left(\mathrm{m}^{2}\right) \text { per person } \\
\text { (after conversion } \\
\text { to useful } \\
\text { production) }\end{array}$ & $\begin{array}{l}\text { No. of } \\
\text { people } \\
\left(10^{\circ}\right)\end{array}$ \\
\hline 70 & 8 & 1 & 12 & 806 & 10 \\
\hline 60 & 14 & 2 & 21 & 469 & 30 \\
\hline 50 & 16 & 6 & 59 & 169 & 95 \\
\hline 40 & 15 & 9 & 91 & 110 & 136 \\
\hline 30 & 17 & 11 & 113 & 89 & 151 \\
\hline 20 & 13 & 12 & 124 & 81 & 105 \\
\hline 10 & 10 & 12 & 124 & 81 & 77 \\
\hline 0 & 14 & 12 & 116 & 86 & 121 \\
\hline-10 & 7 & 12 & 117 & 85 & 87 \\
\hline-20 & 9 & 12 & 123 & 81 & 112 \\
\hline-30 & 7 & 12 & 121 & 83 & 88 \\
\hline-40 & 1 & 8 & 89 & 113 & 9 \\
\hline-50 & 1 & 1 & 12 & 833 & 1 \\
\hline Total & 131 & & & & 1022 \\
\hline
\end{tabular}

However, humans do not live solely by potatoes; if meat is to be included on the menu, approximately twice the land area is required, assuming that only a small amount of meat figures in the diet, since it takes $10 \mathrm{~kg}$ of vegetable matter to produce $1 \mathrm{~kg}$ of meat. This reduces the number of people which Earth can support to

$$
\frac{150+750}{(2 \times 150)+750} \times 145=125 \times 10^{9}
$$

This is still an impressive figure.

However, there will be those who believe that each person requires $1500 \mathrm{~m}^{2}$ to live on and for non-food-related purposes. The maximum number of people who could live on Earth, when excluding meat consumption, would then be

$$
\frac{150+750}{150+1500} \times 145=80 \times 10^{9}
$$

The figures demonstrate that the size of the world's population depends not so much on the land area required for food production, but on the land desired 
for other purposes. To a certain extent, therefore, scope for food production need not restrict the size of the population. Irritation is likely to be a more important factor, along with the need to dispose of waste products.

de Wit made the above estimates in 1975, on the basis of a very simplified calculation. Since then, more accurate estimates have been obtained for various regions using computer simulation models. These models use properties of the soil and climate as basic data and simulate the growth and production of different crops (quantitative analysis). The location, the prevailing climate and the properties of the crop are taken into account, then the potential and attainable production, based on the availability of growth factors, can be calculated. A comprehensive analysis of the potentials of crop growth and food production in various regions of the world, based on soil and climatic conditions was done by Buringh et al (1975). On behalf of the European Community, fifteen years later the Netheriands Scientific Council for Government Policy (WRR) commissioned the Winand Staring Centre (SC-DLO) in Wageningen to carry out an even more detailed analysis. All their estimates show that, on the basis of the potential soil productivity, production levels several times the current ones could be obtained. If the land area suitable for different types of agriculture is determined (qualitative analysis), it becomes clear, for instance, that the land area in Greece which is suitable for arable farming (the most demanding type of land use) is only $10 \%$ of the total area. In the other $90 \%$, the land is too steep (making mechanized agriculture impossible), or the soil is too shallow, too saline, too acidic or too rocky. In other countries, such as Denmark and The Netherlands, more than $50 \%$ of the total area is suitable for demanding forms of land use. Through a combination of quantitative and qualitative land evaluation, a fairly accurate assessment can be made of the potential and attainable yields for different crops under the different conditions found throughout the world. The analysis of SC-DLO was used by the WRR for a study of possible developments in the agricultural regions of the European Community. This study indicated that agricultural production could be several times higher than it is at present. Nevertheless, European agriculture, certainly in the most suitable areas, is more productive than in the rest of the industrialized world and much more productive than in developing countries (Netherlands Scientific Council for Government Policy 1992).

\section{Production efficiency: green revolution}

\section{Labour productivity and production efficiency}

The rise in labour and soil productivity mentioned above is expected to continue for some time, for two reasons.

First, potential production is much higher than actual production. In $99 \%$ of the world's agricultural areas, soil productivity is considerably lower than 
its potential. Worldwide, less than $15 \%$ of potential production is achieved. The most important cause of increasing soil productivity resulting from innovation lies in the efficiency of use of inputs. It will be demonstrated below that, at higher production levels in good production situations, efficiency in terms of input per unit product is higher than at lower production levels. The effect of this increase in efficiency at higher production levels promotes continuing growth in production per unit area.

The rise in soil productivity over the past few decades has been accompanied not only by an increased efficiency in input use, but also by higher labour productivity. Around the turn of the century, the production of one tonne of wheat in The Netherlands required 300 hours of labour, the same amount can now be obtained with about 1.5 hours of labour. The growth in the demand side of the market has been another significant incentive fostering growth in production.

The additional inputs needed to achieve these higher yields are sometimes grouped together on the basis of their energy content (Table 3). In contrast to prevailing intuition and many energy surveys conducted in the 1970s, Table 3 shows that the fully mechanized, high-yielding American maize-growing industry is three times more efficient in its use of energy than are traditional methods of cultivation where all work is carried out by hand or by animal traction and where no industrial fertilizers are used. Merely grouping together all energy inputs,

TABLE 3 Energy production and consumption related to four different methods of maize production

\begin{tabular}{|c|c|c|c|c|c|}
\hline & $\begin{array}{l}\text { Nitrogen } \\
\text { consumption } \\
\left(k g h a^{-l}\right)\end{array}$ & $\begin{array}{l}\text { Yield } \\
(\mathrm{kg} \mathrm{ha}-1)\end{array}$ & $\begin{array}{l}\text { Output } \\
\text { GJ ha- }\end{array}$ & $\begin{array}{l}\text { Input } \\
\text { GJ ha-1 }\end{array}$ & $\begin{array}{l}\text { Output/ } \\
\text { input }\end{array}$ \\
\hline $\begin{array}{l}\text { Mexico } \\
\text { Only human } \\
\text { labour, no } \\
\text { industrial fertilizers }\end{array}$ & s & 1944 & 28.89 & 39.40 & 0.73 \\
\hline $\begin{array}{l}\text { Mexico } \\
\text { Human labour and } \\
\text { oxen, no industria } \\
\text { fertilizers }\end{array}$ & d & 941 & 13.98 & 19.26 & 0.72 \\
\hline $\begin{array}{l}\text { USA } \\
\text { Human labour, } \\
\text { horses, industrial } \\
\text { fertilizers }\end{array}$ & 152 & 7000 & 102.58 & 111.79 & 0.92 \\
\hline $\begin{array}{l}\text { USA } \\
\text { Human labour, } \\
\text { machines, industria } \\
\text { fertilizers }\end{array}$ & 152 & 7000 & 102.58 & 48.2 & 2.14 \\
\hline
\end{tabular}


including food and fuel, is not always useful, nevertheless it shows something. On the basis of direct and indirect energy consumption, this comparison of production techniques shows that the Law of Diminishing Returns, which is valid for single inputs under constant conditions, does not hold for agricultural production as a whole. This is because energy is not an input with a single effect, but a resource which can be used in varying amounts depending on the production level and degree of technological development. The increasing efficiency of energy use demonstrates that technological advances in agriculture make possible increasing yields with a relatively lower unit of input per unit of product.

The reason for this is that the relative costs of fixed activities in agriculture, such as ploughing and sowing, decrease as yield increases. In principle, a farmer does not need to plough or sow more to obtain higher yields. For instance, to obtain modest yields, the acidity of the soil has to be adjusted by applying lime, but higher yields do not require more lime than lower yields. The same applies to plant nutrients. This means that many inputs are not variable costs, but are determined by the decision to grow a particular crop. The number of activities needed to grow a crop in a given production situation requires a set of fixed costs; others, such as application of fertilizer or pest and disease control, can be done in various ways and involve variable costs. The better the production situation through structural improvement, the higher are the fixed costs relative to the variable costs. Therefore the variable costs decrease as yields rise. No farmer will improve water management on his land without improving soil fertility by using fertilizer. He will also ensure that this crop is adequately protected. In areas with a low level of land reclamation, crop protection and fertilizers can be regarded as variable costs, because the efficiency of inputs is generally low. In areas with a high level of land reclamation, they are considered essential and therefore are fixed costs. This statement challenges the widespread prejudice that variation in inputs completely depends on their prices. This does not hold for the primary inputs where substitution possibilities are very limited, but does for the secondary inputs where substitution is possible. For example, weeding may be done mechanically or with pesticides, so that labour and capital may substitute for each other.

One consequence of this increase in fixed activities over variable activities is that at higher yields the applied inputs can be better controlled than at lower yields. In situations where high yields are obtained, growth processes are better understood and managed. In low-yielding situations, the effects of various external factors are subject to a stronger mutual influence. Application of the energy-demanding nitrogen fertilizers is better controlled in high-yielding situations, where the unforeseeable losses resulting from volatilization, denitrification, leaching and immobilization are greatly reduced, because of better water management and soil structure. 
Changes in production situations due to structural agricultural measures, such as improved land reclamation levels, may lead to higher attainable yields. Concomitantly, the yield at which the application efficiency of external inputs, in terms of their use per unit of product, is highest rises. In well endowed regions (good soils, high land reclamation levels, i.e. plentiful water and nitrogen), the production levels at which optimum use of external inputs is realized are high (de Wit 1992). In regions with poor soils and low levels of land reclamation, the production level at which the optimum use of external inputs is achieved is generally low.

At low land reclamation levels, high production may be attained by using very high inputs. The application efficiency per unit of product is in those cases generally very low. Improvement of land reclamation through structural changes in the physical production conditions will increase the efficiency of use of external inputs. Poorly endowed regions or marginal lands are agriculturally unproductive and in environmental terms dangerous. It is hazardous to use them.

Wheat yields in The Netherlands rose from $3500 \mathrm{~kg} \mathrm{ha}^{-1}$ in 1950 to $7500 \mathrm{~kg}$ $\mathrm{ha}^{-1}$ in 1990 , while the output relative to input of direct and indirect energy rose from $145 \mathrm{~kg}$ of wheat per GJ to more than $200 \mathrm{~kg}$ of wheat per GJ. The increase in labour productivity and the concomitant increase in energy input were four- or fivefold over the same period.

Crop protection is also an important precondition for higher yields. It does not take much energy to apply the correct biological, mechanical and chemical crop protection methods, but it does require knowledge and experience. The farmer must therefore be highly skilled. Lack of skill can be compensated for by applying excessive chemical crop protection agents; however, that is bad agricultural practice. Integrated protection against diseases and pests, in which as much use as possible is made of their natural enemies and the crops' resistance, together with preventive phytosanitary measures, requires frequent field observations. By using suitable measures at the right time and in the correct way, much loss of production can be prevented. The same applies to other agricultural practices.

High production levels do not, therefore, necessarily require more chemical energy in the form of fertilizers, machines and pesticides; rather they call for well-trained farmers who are capable of taking well-considered decisions throughout the growing period of a crop. Brain power is much more effective than energy in the form of tangible inputs, and the amount of energy it takes to think is negligible.

Yields continue to increase until the attainable level is reached, which for a high level of land reclamation lies only just below the potential yield (Fig. 4). The increase in yield per unit area is determined not so much by economic factors as by the rate at which knowledge and experience are assimiliated and put into practice by the farmer. If it is economically feasible to farm, suitable resources and technology should be properly used. In this way of thinking, it is not a matter 
of whether to use more or less technology or inputs, but whether one is going to farm or not.

\section{Green revolutions}

The rise in labour and soil productivity discussed above has been accompanied by a number of breaks with tradition. In the late 1940s and early 1950 s there was a sudden increase in the growth of grain production per unit area in the Western industrialized world (Fig. 1). This first green revolution, as it was known, was the result of a combination of developments in several scientific disciplines. Short-stem varieties of plants, which had been bred by Heine during the Second World War, were introduced; the use of nitrogen fertilizers increased rapidly; herbicides were introduced. The resulting rise in yield and the rapid mechanization of farm work raised labour productivity to unprecedented levels.

This first green revolution (which went largely unnoticed by the public) was followed in the late 1960s and early 1970s by a second green revolution in Asia, particularly India, China and Indonesia. The increase in productivity that occurred there ended the structural food shortages which had plagued that region since the early 1950s, despite the growing population.

Many parts of the world, particularly Africa and parts of the Middle East, now need a third green revolution, because they have never experienced the kind of explosion in productivity described above and have burgeoning populations.

\section{Environmental effects of agriculture}

\section{Environmental effects of poverty}

For centuries humans have had to face the problems which arise when land is not used properly. The depletion of soils and overuse of irrigation systems have caused erosion and the irreversible loss of good agricultural land. The bare hills around the Mediterranean, particularly in Greece, bear witness to this tragedy. Sand drift in The Netherlands was caused by human activity. The overexploitation of the natural environment by the Aborigines in Australia made large areas of land unsuitable for agriculture.

Until the green revolutions, the harmful effects of agriculture on the environment and natural habitats were the result of the over-exploitation of the potential of agro-ecosystems. This still constitutes the main threat to the majority of the world's agricultural regions. Over-exploitation of this kind is not confined to developing countries. Large-scale agriculture-which virtually amounts to overcropping-in Australia, the USA, South America and the Commonwealth of Independent States could seriously threaten the continuity of agriculture there. The dust storms which occurred in the USA in the 1930s could now happen again as a consequence of cavalier environmental 
management. Agricultural systems geared merely to short-term economic gains can have a drastic effect on the environment and threaten agriculture in the long term. Erosion is a particularly serious threat. Agricultural methods which ensure that soil does not become depleted, that layers of soil do not wash or blow away and that the structure and texture of the soil are kept intact are available, but according to current economic thinking are often unattractive.

A good farmer ensures the continuity of his farm, but can do so only if the right preconditions are created and there is no net economic gain to be had from exhaustive cultivation. The threat to the world's food supply as a result of underutilizing inputs and overly extensive agriculture is enormous.

A typical example is found in Africa. Sub-Saharan Africa is the only part of the world where food production per capita has declined over the past two decades as a result of an increasing population on one hand and lower yields on the other. The latter has, among other things, been attributed to catastrophes such as drought and infestations of locusts. A more gradually developing problem in the region, less readily linked to food shortages of the recent past, is declining soil fertility.

To calculate nutrient balances, Stoorvogel \& Smaling (1990) partitioned the arable land of 38 countries in Africa into agro-ecological zones, characterized by rainfall, current soil fertility level, cropping systems, application of fertilizer and manure, crop residue management and erosion control. The flow of nutrients into and out of the soil was assumed to be governed by five input and five output factors.

The net balance of inputs and outputs of nutrients was negative in all countries considered (Fig. 5). The highest annual nutrient depletion rates were found in densely populated East Africa. West Africa had moderate to high depletion rates; Central Africa and the Sahel region had moderate to low rates. Soils in the Sahel region are so poor that little is left to lose.

The highest depletion rates are in most cases associated with erosion of the top soil rather than export in crop products. The difference between inputs and outputs is covered by the soil nutrient reserves: with progressive depletion, the soil nutrient supply decreases and crop production will decline. On the whole, nitrogen deficiency is almost universal in Africa and fertilizer application is a prerequisite for crop production. However, because of interactions with other nutrients, application of nitrogenous fertilizers only leads to more efficient 'mining' of other soil nutrients. Nutrient deficiencies can be corrected only by integrated use of organic and inorganic sources of various nutrients.

\section{Environmental effects of wealth}

This underutilization of inputs in large areas of the world is in sharp contrast to the overutilization prevalent in Western Europe. A surplus of animal manure and the virtually constant price of fertilizers over the last 15 years in Western 


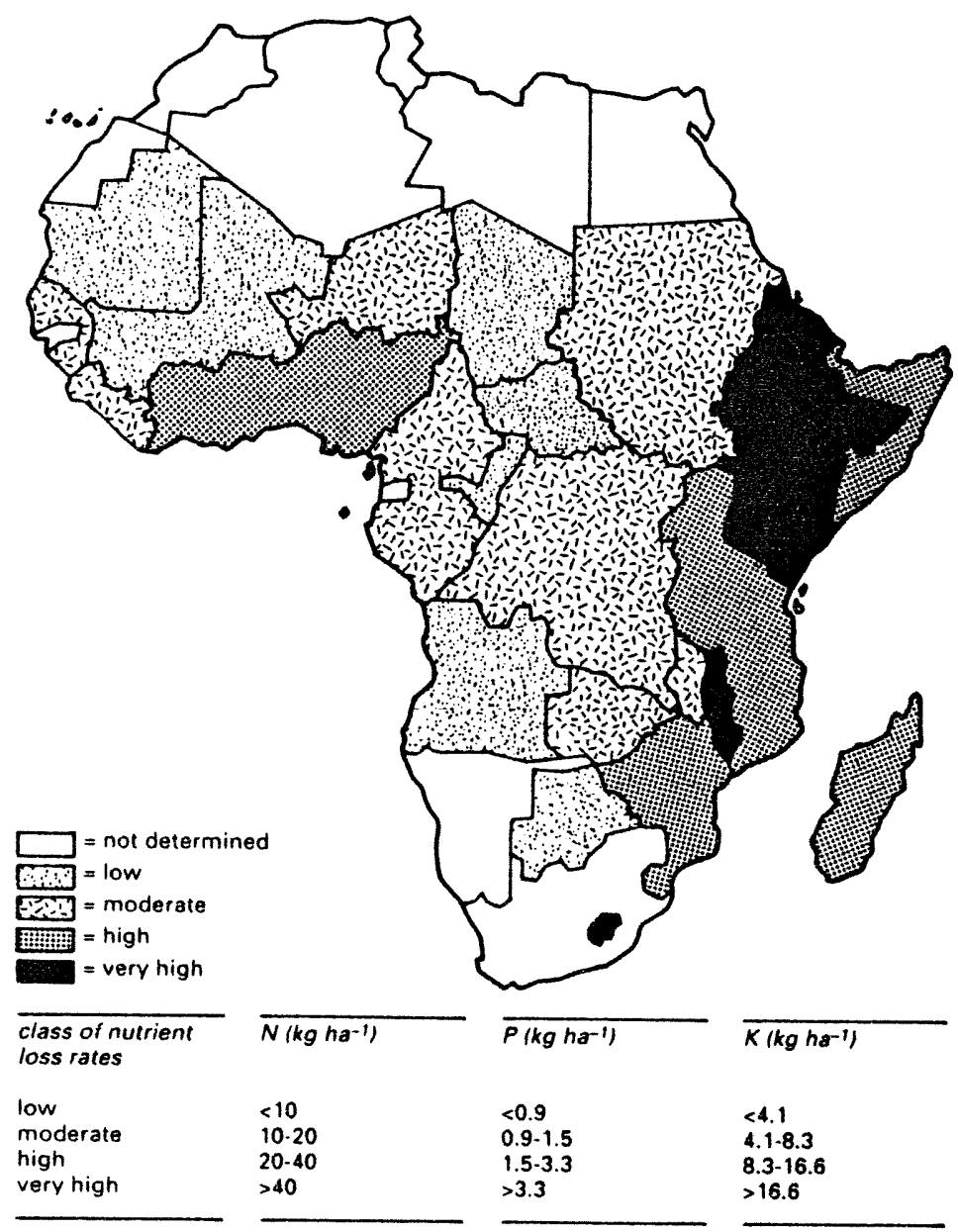

FIG. 5. Rates of nutrient loss from arable land in Sub-Saharan Africa in 1983. From Stoorvogel \& Smaling (1990).

Europe, which has been a consequence of improved production processes, has meant that the relative price of fertilizers is now so low that farmers are encouraged to overuse it. In The Netherlands the excessive use of nitrogen from animal manure and fertilizers has reached drastic proportions. An average of $550 \mathrm{~kg}$ of nitrogen is applied to each of The Netherlands' $1.1 \times 10^{6}$ ha of grassland each year in the form of fertilizers and animal manure; only $75 \mathrm{~kg}$ of nitrogen from each hectare finds its way into the milk and meat produced. Large amounts of nitrogen therefore accumulate in the environment. 
The discrepancy between nitrogen input and output is caused partly by the unclear relationship between the technically and economically optimum levels of input of nitrogen. The maxim that 'what doesn't do any good can't do any harm' has been applied in the case of nitrogen, but is untrue. Technically, no benefit is gained from the overuse of nitrogen: it does not result in higher yields. It produces indirect economic benefits through feed intake by animals. However, that can be attained technically in a much better way through changes in diets. The implicit gap between the technical optimum and the economic optimum would thus seem to be one cause of this overutilization. However, because overuse of nitrogen fertilizers is of limited economic benefit, the gap between these optima cannot be the only reason for this practice. In simple terms, overuse can result in 'peace of mind' for the farmer: the thought that, at any rate, the crop has sufficient nitrogen. The constraints on farmers' finances these days prompt many of them to adopt this attitude, to combine maximum yields with minimum risks.

The best way of stopping the overuse of nitrogen fertilizers is to give farmers better information about fertilizing their land, the link between fertilizers, crop growth and the environmental impact of overuse of fertilizers. This will not in itself be enough: a financial incentive in the form of a tax on nitrogen fertilizers is required, on theoretical macro-economic as well as practical grounds. This would reduce the actual use of nitrogen fertilizers to approach the technical optimum (generally $200 \mathrm{~kg}$ of nitrogen ha ${ }^{-1}$ per year for grassland). Another environmentally favourable development is the shift in agricultural production towards more productive land, where less nitrogen leaches into groundwater and much higher nitrogen output in products is achieved per unit of input. Harmful environmental effects resulting from prosperity can therefore be solved by concentrating production in smaller areas, within integrated agricultural systems, which also frees areas for natural development.

Detrimental environmental effects resulting from the underutilization of inputs can be tackled only if more use is made of external production factors (mainly fertilizers and good water management). Particularly in areas of low soil fertility, care must be taken to restrict expansion of the area under cultivation. Expansion could lead to use of marginal land, quickly causing soil depletion, after which the land is abandoned. Uncontrolled expansion of land under cultivationcaused by rising populations-entails huge environmental risks, which can be averted only if a rise in productivity can be achieved in fertile areas, within limits which ensure that the environment is protected.

\section{Primary and secondary production}

So far, this paper has been devoted almost exclusively to crop production. Animal production is derived from crop production. As a result of increasing prosperity and therefore increasing demand for animal products, there has been 
a sharp rise in the demand for animal feed. This generally requires 4-10 times more agricultural land than production of vegetable crops that are directly consumed by humans. Thus, a growing demand for meat results in more land being used to grow crops. The rise in productivity per unit area discussed above implies that this increase has been limited.

In the past, crops for animal consumption were produced on the farm where the animals were kept. This is still the case in the majority of the world's agricultural systems. However, in The Netherlands, the existence of the port of Rotterdam and its specialization in the import of cheap animal feed, and the fact that farms are too small to produce food for the large number of animals kept on them, has meant that the link between animal and vegetable production has to a large extent been broken. The crops required to feed livestock are produced elsewhere in the world, while animal production-mostly in the form of dairy products and meat-takes place in The Netherlands. A significant proportion of animal products is exported, while the nitrogen in the manure produced remains behind, creating huge environmental problems. Restoring the link between animal and crop production would go some way towards solving these. This would require both technical measures, such as improvements in the composition of animal feed, the transport and processing of manure, and a reduction in the number of livestock. This 'luxury' problem is not intractable: the means exist, it is merely a question of finding the political will.

\section{Acknowledgements}

I would like to thank Bjørn Dirks and Harrie Lövenstein for their assistance in the preparation of this paper. A great deal of the information is taken from de Wit (1971).

\section{References}

Austin RB, Ford MA, Morgan CL 1989 Genetic improvement in the yield of winter wheat: a further evaluation. J Agric Sci 112:295-301

Buringh P, Van Heemst HDJ, Staring GJ 1975 Computation of the absolute maximum food production of the world. Wageningen Agricultural University, Wageningen de Wit CT 1971 Voedselproduktie: verleden, heden en toekomst. Stikstof 6:396-408 de Wit CT 1972 Food production: past, present and future. Stikstof 15:65-80 de Wit CT 1992 Resource use efficiency in agriculture. Agric Syst 40:125-151 Kropff MJ, Vossen FJH, Spitters CJT, de Groot W 1984 Competition between a maize crop and a natural population of Echinochloa crus-gall (L.). Neth J Agri Sci 32:324-327 (synop)

Netherlands Scientific Council for Government Policy 1992 Ground for choices. Four perspectives for the rural areas in the European Community. Sdu Publishers, The Hague (Rep Gov 42)

Pimentel D, Hall CW 1984 Food and energy resources. Academic Press, New York

Sibma L 1968 Growth of closed green crop surfaces in The Netherlands. Neth J Agric Sci $16: 211-216$

Stoorvogel JJ, Smaling EMA 1990 Assessment of the soil nutrient depletion in SubSaharan Africa. Report 28. Winand Staring Centre, Wageningen 


\section{DISCUSSION}

Kenmore: One pest we will be hearing a lot about in the next few days with reference to rice is the brown plant hopper. This eats and excretes sugar solution from the phloem of rice plants-about $1 \mathrm{mg}$ of dry matter per day. So it would take about one million plant hoppers on one hectare to eat the equivalent of $1 \mathrm{~kg}$. One million plant hoppers is four per plant at normal planting densities, which is less than the commonly observed level. The question is what happens to the crop yield? Does the plant hopper really impose any limit to production? I have a feeling it's just another sink: the crop will respond, over a fairly wide range of pest densities, to that additional sink.

Rabbinge: If you calculate the amount of assimilates consumed by a particular insect, in general terms it's always very low, compared with the plant growth that potentially can be achieved. If the insect is just consuming leaf matter or dry matter, in many cases it is just another sink to the crop that, in situations where sinks are limiting crop growth, may promote production. Leaf folders in rice are a typical example. If the leaf folder is not present at the early stages of plant development, limitation of sink size may limit development of the source. So in some cases, an insect or a disease actually raises production. Many crops growing under optimal conditions are not source limited, they are sink limited.

Secondly, many of the pests, in addition to the direct effect of consuming leaf mass, have an indirect effect. For example, aphids promote early senescence; they also reduce the efficiency of light use and photosynthesis. These effects are much more severe than the direct effect of consuming assimilates and may cause damage at a much lower level of insect infestation than one would predict just on the basis of the energy balance. Thus, in some cases, it is better to have 'pests' than to be without; however, in other cases, even a limited infection may cause heavy losses.

Kenmore: If we are trying to sustain a productive ecosystem in a field, an indigenous second trophic level (herbivores) may be needed to keep the third trophic level (predators) happy and dense enough to deal with the occasional pulse of immigrant herbivores.

Rabbinge: Yes, a crop that is completely free of insects or herbivores is a sterile environment. In such situations, effects due to sink limitations are present. The plant may therefore not fully use the incoming radiation for growth and production.

Varma: Another important indirect effect of insects like aphids, leaf hoppers and whiteflies is the transmission of viral diseases.

For direct effects, Marion Watson (1967) worked out that if you left aphids unchecked, they would suck off $100 \mathrm{lb}$ of sap per day from each acre of sugar beet crop. Fortunately, that does not happen in any system because ecological balance is maintained through predators and parasites. 
Jayaraj: There are two other issues concerning herbivory by sucking insects. One is the phytotoxaemia caused by certain insects that introduce toxins along with their saliva. Secondly, there is the removal of plant auxins along with the plant sap. It is not merely the defaecation that counts, these factors are also important.

I would like to comment on four inputs-nutrients, water, crop variety and crop protection materials. In many countries that are poor in natural resources, you commonly find wrong use of fertilizers. The non-availability of fertilizers at the right time is a major constraint. The main problem is that if farmers don't get financial credit on time, they are unable to purchase the fertilizers. So the limiting nutrient, namely nitrogen, is applied when it can be obtained, which is often not at the recommended times. This has resulted in increased pest and disease activity, particularly in rice-tungro virus and leaf folder. We need to promote more integrated nutrient management for sustainability, including greater use of organic manure, like green manure and biofertilizers.

The second input is water. Very often, Asian farmers inundate rice fields to suppress weeds, but this predisposes the crop to attack by the brown plant hopper and other pests. These occur at high densities at the critical crop growth phases and, again, dry matter production is greatly affected.

Thirdly, crop variety: any production situation is governed by the interaction among three factors-genotype, crop management and the environment. Crop management varies according to the resource base of the farmer. Recently, the environment has become completely distorted, so the optimum dry matter production of the genotype is not obtained.

Lastly, there is considerable wastage of chemical pesticide input owing to incorrect formulation, the wrong method of application and so on. This may also be true with the new biopesticides, pheromones, etc, that are becoming available. The application equipment should be based on the needs of the local situation. If these points are observed, we can promote sustainability in food production.

Zadoks: The correct timing of agricultural measures is a point that is often overlooked; it seems to me that this is especially so in tropical countries which are adopting modern technology. Part of this is due to the lack of credit at the right time, as you said, and here we enter the realm of social sciences. This is why we have so many social scientists at this meeting; we cannot work towards sustainable crop protection without support from social scientists.

Rabbinge: I support the comment that proper nitrogen fertilization is very important for maximum efficiency. I agree that very often nitrogen is not applied at the right moment. When it is applied at the proper time according to the production situation and the stage of crop development, it has a synergistic effect.

If you plot nitrogen uptake against the application rate, you see that the basic amount of nitrogen available to a plant without any treatment varies according 


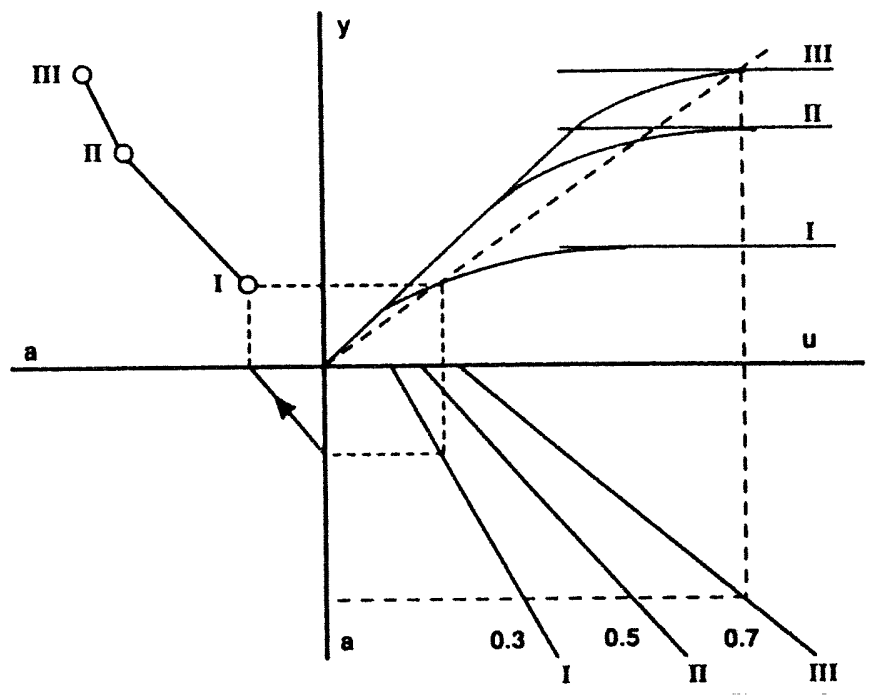

FIG. 1. (Rabbinge) The effect of various levels of land reclamation (I, II and III) on the relation between fertilizer uptake $(u)$ and yield $(y)$, on the relation between fertilizer application rate (a) and uptake, and on the relation between fertilizer application rate and yield.

to the level of land reclamation (Fig. 1). At a better level of land reclamation, the level of basic nitrogen available at which an equilibrium between inputs and outputs is reached is higher. The slope of this line, which reflects the efficiency of use of nitrogen, also changes. At a better level of land reclamation, the efficiency increases. If you have proper control of pests and diseases at the right times, you see a similar shift-an increasing basic amount of nitrogen available to the plant and better use of the nitrogen. So by treating with nitrogen in the right amount and at the right time, you can increase efficiency synergistically. This is a very important point. It means that enough of these basic elements have to be available, therefore it's very important to apply the fertilizer at the right moment. In many countries in the developing world, shortage of nitrogen is the problem. So there is a continuing danger of poverty, because the nitrogen or the fertilizer or other input is not available at the right time. On the other hand, for example in some parts of Western Europe, there is tremendous overuse of external inputs, such as nutrients or pesticides, which is hazardous for the continuity of the whole system and is very unsustainable.

Kenmore: We are talking about sustainability, not in an idealistic sense of a closed system, but as sustainable growth in food production, without which we cannot open our mouths in Asian policy-making circles. We must sustain growth, not just sustain ecosystem flow. Basically, building up the productive parts of the ecosystem-which for insect control means predators, the third 
trophic level-early in the season and keeping them available, is not only the cheapest but also the most reliable response to crop phasing, where there are critical periods of yield vulnerability to stress, including fluctuations in the populations of herbivores. Evolution gives us a stage, as it were, to play on, and we need to maximize what we can do on it. This means building up predator densities to levels that are routinely attainable and can handle, in the case of many rice insects, a change in herbivore density of an order of magnitude in 3-4 days.

Varma: I am very happy that Dr Rabbinge expressed the belief that we can feed a global population of 80 thousand million people. That provides grounds for optimism for countries with growing populations. Let's hope it is possible.

You mentioned that in the United States there has been an increase in production of wheat per unit area. But Ruttan (1987) claimed that in the United States the increase in production per unit worker was greater than that per unit area between 1880 and 1980. During the same period in countries like Japan and Germany, where the development started with a relatively high population:land ratio, the increase in output per unit land has been largely responsible for the growth in total productivity. In contrast, in India, production per unit labour has declined slightly (Varma 1989). Recently, in parts of India, a decrease in production of food grains has been observed in areas where high inputs are used (Varma \& Sinha 1992). Have you come across such a decrease in yield under European situations?

Rabbinge: We do not have that situation in Europe as far as I know. For the majority of crops, yields are still increasing-that's creating problems for the European Community, because we have a surplus of production. One reason for this increase in productivity, especially in southern parts of Europe, is that there is still a big gap between potential yields and actual yields. In many cases, they are producing only $20-30 \%$ of the potential; whereas in parts of Great Britain, Schleswig-Holstein in northern Germany and in The Netherlands, they are producing $80-90 \%$ of the potential.

In India, the stagnation of yields may be due to the fact that the various external inputs are probably not applied in the proper combinations.

Swaminathan: I am glad this was the opening paper, because in India and other developing countries, our greatest concern in agricultural research is how to achieve as much of the potential as possible, without damaging the environment. Professor Varma mentioned yield stagnation, for example in the Punjab. Already the farmers are producing $10-12 \mathrm{tha}^{-1}$ of rice and wheat, with a harvest index of about $40 \%$ (i.e. $40 \%$ of the energy from total photosynthesis goes to grain formation). Sugarcane farmers in India are almost realizing the full yield potential: in parts of Tamil Nadu state nearly $90 \%$ of the production potential has been achieved. The major problem is: at what cost can it be sustained? 
The Chinese increased their total production of food grains from 300 million tonnes to 400 million tonnes between 1980 and 1990 (World Bank 1991, unpublished). They would like to increase it by another 100 million tonnes between now and the year 2000. But the increase to 400 million tonnes was achieved largely through the use of additional mineral fertilizer and there is now nitrate pollution of the ground water. In India, the areas where sugarcane is being produced at very high yields $\left(200\right.$ to $\left.300 \mathrm{tha}^{-1}\right)$ are all areas where ground water is being depleted very rapidly.

So the challenge before this meeting is: under conditions where we must achieve as much of the potential production as possible, how do we do it such that we don't jeopardize the prospects of long-term production? In India, almost $50 \%$ of the land area is under agriculture; the area of forest has dwindled enormously, land is a shrinking resource for farming. Under these conditions, the only way to increase overall production is to reach the potential production level, but what are the implications? In Europe production is rising, but they have high prices and very high subsidies - the economic aspects of productivity improvement are important. Are there clear studies, in The Netherlands for example, on the ecological implications of this very high level of achievement in terms of potential production?

Rabbinge: In many situations in The Netherlands, sustainability has been endangered by the overuse of external inputs for two reasons. First, the crop rotations are too narrow. Potato always gives a better economic result than do small grains, so frequently potato occurs too often in the rotation. This creates difficulties and necessitates fumigation of the soil to prevent an upsurge of nematodes and other pests. If we return to broader crop rotations, there will be a considerable reduction in pesticide use.

Secondly, there is incorrect use of pesticides. If these were used in the proper way in the European Community, we have calculated that annual pesticide use could be reduced from 400 million $\mathrm{kg}$ of active ingredients to between 40 and 80 million $\mathrm{kg}$. This could be achieved in three ways. (1) Use of the best land at high production levels with very high efficiency and low emissions. (2) Adoption of crop rotations that prevent systematic overuse of pesticides and better integration of crop and animal production. (3) Application of good housekeeping methods, such as integrated pest and disease management.

The same is true for nitrogen. There has been tremendous overuse of nitrogen because it is very cheap. The actual price of nitrogen during the last 20 years has not increased, so the relative price has decreased considerably. Now we are saying, we should have broader crop rotations and more intelligent use of fertilizers. Many farmers have already decreased the nitrogen input. For example, in potato and sugar beet, during the last 20 years, nitrogen input has been reduced by more than $50 \%$ but yields have still increased, because of better use of external resources. 
So there is certainly a way to increase production in India and other developing countries, but it needs a lot more knowledge of how to manipulate the cropnot only in the heads of research workers, but in the farmer's fields, which of course is the difficult thing.

Royle: All this high input doesn't necessarily mean that we are very effective at controlling pests and diseases in Europe. Husbandry methods have inevitably changed during intensification, which has created new problems. There is evidence for shifts in the dominance of some pests and diseases. Surveys have indicated that relative to changes in production levels over the last 20 years, we are no better at controlling certain diseases now than we were then, even with heavy pesticide use. This makes a scenario which can be difficult to modify towards sustainability, and in which it will be difficult to find methods that are appropriate for sustainability.

Jayaraj: The input efficiency varies from temperate to tropical situations. In the tropics, the loss of fertilizer nitrogen, due to run-off, seepage and volatilization, occurs much faster. The organic carbon content is degraded rapidly because of the high temperatures and light intensities, which are not found in temperate climates. So sustainability is more at stake in the tropics than in the temperate regions. We may have to develop technology to compensate for this.

In this context, Dr Rabbinge's comment that ecotechnological insight and maximal biological self reliance are vital for development is highly significant. In India recently, Dr Swaminathan has introduced the biovillage concept to promote everything biological to sustain agriculture. This seems to be one answer, to promote biological self-reliance.

Lastly, methane emission, increasing UV irradiation and the effects of other greenhouse gases will all be serious concerns with regard to sustainability. Studies have been started by the Indian Council of Agricultural Research and in many other countries on the effects of these greenhouse gases on plants. We should also observe the effects on pests and diseases, on the expression of host plant resistance to pests and diseases, on the natural enemies and on artificially introduced biological control agents.

Saxena: Concerning high input agriculture, plants, particularly green plants are intrinsically resistant to a certain degree of herbivory. But if they are stressed by nutrient imbalance, their innate defences break down. We determined the comparative allelochemical fractions in rice plants. Production of these chemicals per unit plant was lower in plants grown under stressful conditions than in plants grown under conditions of proper nutrient balance. Several other abiotic stresses, e.g. salinity, iron toxicity, aluminium toxicity and high temperature, have the same effect. Sustainability could be improved by the use of cultivars that are tolerant to these abiotic stresses.

Rabbinge: Nutrient imbalance in a crop creates difficulties, not only because of direct stress, but also because it often promotes the rapid development of 
particular pests and diseases. If there is overuse of nitrogen, then there are many free amino acids in many of these crops, which favours a stronger upsurge of, for example, aphids. So it's necessary to minimize the use of nitrogen in such a way that you maximize the efficiency of use of the phosphorus and potassium. It's always this mini-max relation, among all these external inputs. At the optimum levels, when you have the proper combination of these external inputs, then you have a synergistic effect of all the different inputs, including crop protection measures-and that is our ultimate aim.

\section{References}

Ruttan VW 1987 Agricultural research policy and development. FAO, Rome (FAO Res Technol Pap 2)

Varma A, Sinha SK 1992 Sustainable development through long-term biotechnological alternatives in agriculture. In: Daniel RR, Ravichandran V (eds) Proceedings of the International Seminar on Impacts of Biotechnology in Agriculture \& Food in Developing Countries. Committee on Science and Technology in Developing Countries (COSTED), Madras, p 44-57 Watson MA 1967 Epidemiology of aphid-transmitted plant virus diseases. Outlook Agric
5:155-166 